\title{
The Impact of the Global Financial Crisis on China's Banking Sector
}

\author{
MICHIEL HAASBROEK AND JÖRN-CARSTEN GOTTWALD
}

\begin{abstract}
The banking sector had long been left at the fringes of China's reform policies. Major initiatives of the 1990 and early 2000s helped to balance the need for modernization and internationalization with the objective of preserving political control. When the Global Financial Crisis (GFC) erupted in 2007, it hit the Chinese economy but predominantly in its export sector and much less in its financial sector. Yet when exports collapsed and factories closed in the winter of 2008/2009, the Chinese leadership implemented an ambitious stimulus program and used its leverage over the financial sector to re-start economic growth. These factors - GFC and domestic stimulus - created a series of intended and unintended outcomes. Financial reform in China entered a new stage signalling a profound change in China's banking sector. These changes follow two sometimes contradictive, sometimes mutually reinforcing reform dynamics of top-down policies and bottom-up innovation. In this article we follow an institutional approach and discuss the intensified participation of China's big banks in the Go Out strategy, followed by a shift in the pattern of lending. One factor in this change is the rise of shadow banking and particularly an explosive growth in internet-based financial services. Thus, while the initial reaction to the GFC re-emphasized direct, top-down state involvement in the banking sector, the outcomes of the GFC, China's policies and business innovations have facilitated profound bottom-up changes.
\end{abstract}

Keywords: Global financial crisis; China; banking; internet finance; regulatory reform

\section{Introduction}

More than thirty years since the 3rd Plenum of the 11th Central Committee of the Communist Party of China (CPC) approved the policies of reform and opening up in 1978, the Socialist Market Economy of the People's Republic of China (henceforth China or PRC) faced one of its most crucial challenges: the financial crisis which erupted in the United States in 2007 transformed China's international environment henceforth so conducive for its modernization. The crisis sent shockwaves from the US sub-prime mortgage sector into the financial, economic, social and 
political realms of practically all advanced and emerging economies. China experienced a sharp decline in exports and economic activity in the winter of 2008/2009. Its banks, insurance companies and large industrial enterprises, however, seemed to master the external shock astonishingly well, as shown in their profit margin increases and expanding balance sheets. The institutional framework for China's financial service sector proved resilient. A massive economic stimulus programme rekindled economic growth. As a by-product, however, disintermediation and rapid credit growth threatened financial stability. The crisis had caught China's financial sector in the middle of a reform drive, which had to be taken to a new stage of intensified internationalisation, marketization and diversification (Zhou Xiaochuan 2015). ${ }^{1}$ Regulatory reform and deep changes in China's banking sector went high up the political agenda in spite of its threats to a Leninist party-state safeguarding finance as a central pillar of its political power.

In studies of regulatory reform, crises are often interpreted as critical junctions that stimulate departure from path-dependent evolution of rules, norms and codes of conduct in the form of innovative reforms (Kroszner, Randall \& Strahan 2000). They affect a multi-facetted process of change in reaction to the crisis conducted by 'a multitude of heterogeneous actors operating in a multitude of different sites' (Mayntz 2012:12). Looking at the recent history of the Chinese party-state in rebuilding its financial services sector, this link between global crises and institutional innovation deserves further study. While earlier works have emphasized the significance of the party-state in the politics of regulatory reform in China's financial services sector, we propose a slightly different perspective: in the tradition of an actor-centred historical institutionalism (Farrell \& Newman 2010; Mayntz 2012; Mayntz \& Scharpf 1996) we analyze the changes in China's banking sector as politics of regulation resulting from a political and entrepreneurial reaction to changes in the political and business environment at the national, local, and global level.

The politics of regulation in China's financial sector are typified by the combination of a Leninist party-state with regulatory mechanisms in an East Asian developmentalist setting (Heilmann 2005, 2011; Pearson 2007,2011 ), aptly characterized as a case of 'financial repression' (Heep 2017: 213). Thus, regulation in China is confronted with two conflicting objectives: allowing greater liberalization promoted by regulatory agencies to provide a rule-based structure for economic activity in accordance with international expectations, norms and rules; and to enhance control and mechanisms for direct intervention by the party- 
state. While China has established a series of regulatory commissions and other specialized bodies for financial services regulation since the late 1990s, these organizations are part of the hierarchy of the partystate. In China, political organs overrule regulatory bodies when this is deemed necessary to support the objectives of the (central) state or the CCP. Their members are cadres, whose careers are centrally planned and supervised. The party-state, however, rarely acts as a unitary actor. Essentially, strategic industries, of which banking is one, suffer from poorly demarcated regulatory influence from state-level planning bodies, such as the State-owned Assets Supervision and Administration Commission of the State Council (SASAC) or the PRC National Development and Reform Commission (NDRC), and the industry-specific regulators China Securities Regulatory Commission (CSRC), China Banking Regulatory Commission (CBRC) and China Insurance Regulatory Commission (CIRC) (Gottwald \& Collins 2012; Martin 2012). ${ }^{2}$

A strict hierarchy based on Leninist party-state structures is confronted with complex rivalries and processes of negotiation among different groups of actors. In a seminal work Shih (2007) pointed to the existence of two rival factions, technocrats and generalists, that influence the supply of credit, whereby the generalists support economic growth by means of credit extension and the technocrats develop policies that limit resulting inflation and bubble risk. This has a significant effect on both the overall path of institutional change and the reaction to external shocks such as crises.

This article will focus on the developments in the financial sector in China immediately after the 2008 GFC. This sector of the economy exhibits a variegated development: on the one hand, there was a retrenchment towards greater state control, with the state giving guidance on the direction and magnitude of credit growth and pushing the state-controlled banks to increase lending. On the other hand, a new set of reforms of the financial sector were introduced in order to support a structural shift to a greater reliance on domestic consumption, foster a more entrepreneurial culture, and provide better access to formal financing for the SME segment and private companies. This was accompanied by an implicitly acknowledged wave of financial innovation at the local level.

Thus, the financial sector was at the heart of China's policy response to the GFC. It underwent significant change, moving from an emphasis on bank lending (heavily biased to SOEs) to a more dynamic sector that managed to escape regulatory reins at times. In this period, Chinese 
banks grew to become some of the largest in the world, supported by a loose monetary policy and the continuation of financial repression (Lardy 2008; Subacchi 2017: 49-67). Shadow banking developed quickly, with the implicit support of the central authorities triggering a process of dynamic innovation outside the regulatory framework. Through their enormous profitability, bolstered by a secured high net interest margin, banks were able to support their capital base and confidently look to the future of increased regulatory requirements that followed the implementation of the Basel II rules in China. But the lending spree following the GFC led to an on-going demand for more credit. This intensified the competition for deposits resulting from earlier hesitant moves to liberalize interest rates as a means of modernization. Various reform initiatives were announced, some of them tested, few implemented (Andreosso-O'Callaghan \& Gottwald 2013), and most increasingly linked with the liberalization of the RMB and its incorporation into the Special Drawing Rights of the IMF (Prasad 2016: 141-149). China's new role in global finance stepped up the pressures resulting from international politics on the domestic reform drive (Wen Jiabao 2010; ${ }^{4}$ Dai Xianglong 2011). ${ }^{5}$

The banking sector in China saw an impetus for four distinct trends following the GFC: 1) increased orientation towards foreign markets as part of a re-emphasized national policy, the 'Go Global Strategy' also supporting the internationalisation of the RMB; 2) a significant shift in the patterns of credit provision which is closely linked with;3) financial disintermediation and; 4 ) the rise of shadow banking. Shadow banking became a hotbed for innovative practices by fostering China's explosive growth in e-commerce for the development of new financial products and services (internet finance). These developments all contributed to a structural shift in access to formal and informal financing between sectors and forms of ownership.

\section{China's Institutional Change as Regulatory Politics between Domestic Demands and External Pressures}

Throughout the reform period, the policies of market creation adopted by the leadership of the CPC were aimed at preserving its dominant position in Chinese politics. Research on China's economic policies has been dominated by institutional analysis following a top-down logic of centrally initiated reforms or a bottom-up perspective of entrepreneurial activities, first ignored and later acknowledged by the state (Nee 
\& Opper 2013). The interplay of top-down and bottom-up initiatives generated a new form of governance. The policy process allowed for extensive experimentalism under the 'shadow of hierarchy' (Heilmann 2008) where the central leadership could encourage local actors to test new policies relying on the party-state for revision or ex-post legitimization. The politics of market creation, control and regulatory reforms followed a similar pattern of actors reacting to incentives provided by an institutional framework, which they actively sought to influence (Levy-Faur 2012a, 2012b; Mayntz 2012). 'Markets' in this context are institutions setting incentives for actors to pursue their interests (Williamson 1982; North 1991), including the will to introduce institutional change (Mayntz \& Scharpf 1998). Institutions are thus the product of actions, are embedded in specific sociocultural contexts, and require consistent supervision, preservation, attention and innovation. Due to the specific nature of financial markets, the politics of financial regulation involve an on-going race between regulators and regulates, powerful external actors pursuing their interests and the high volatility of massive capital flows (Gottwald 2012). Thus, while regulatory reforms can successfully be modelled as a process of institutional change, this can be drastic and triggered by both changes in domestic constellations and external shocks (Mayntz 2012).

In China, the policies of market creation in the financial sector did not follow the logic of creating an optimum framework for a maturing market economy. Rather, they sought ways to get the best out of two realities: the control of a key sector of the economy by a Leninist partystate, and open access for foreign and domestic capital into Chinese business (Heilmann 2005; Collins \& Gottwald 2014). On an individual level, this allowed leading representatives of the party-state to pursue business opportunities. On a collective level, it prepared the ground for a much more efficient and comprehensive utilization of Chinese and foreign savings for the unqualified pursuit of economic growth. Reform of the financial sector was closely tied to the reform of the state-owned enterprise system and deferred to a relatively late moment in China's process of opening up (Subacchi 2017: 29-48). Once it was approached with remarkable stamina by the Zhu Rongji government in the late 1990s, it followed the fundamental path of attempting to outgrow its inefficiencies and structural problems (Huang et al. 2005).

China's response to external financial crises thus included the elements of a top-down regulatory change, i.e. the introduction of new policies and institutions, as well as bottom-up processes of adapting to 
the new framework and its inherent incentive structures. The specific context for China's banking industry is constituted by formal and informal institutions, including the networks that make up Chinese politics. Unanticipated consequences come in the form of the macro-economic and financial repercussions of previous economic policy, coupled with the outcome of external events and developments. Yet the resulting path-dependency is threatened and potentially disrupted by crises. As Gourevitch (1978) pointed out, severe economic crises lead to a destruction of existing economic equilibriums, necessitating new paradigms and thereby opening up for learning and new ideas. A clear example in the context of this article is the rise of financial disintermediation, or shadow banking (see below).

While China's regulatory responses to the GFC has been the subject of several studies (Herd et al. 2010; Huang 2010; Walter \& Fraser 2011), the impact on China's banking industry, particularly the massive push for innovation and competition as an unintended consequence of an external shock - the GFC - and its economic policy response - the 2008 stimulus programme - deserves our attention. The GFC increased the pressure on the Chinese government to further improve its macro-economic control. Both, GFC and macro-economic control challenged the structure and behavioural patterns of China's banking system, leading to calls for further improvement of the regulatory framework. ${ }^{6}$ As Yu Yongding noted in 2010, the 'current crisis also presents a good opportunity to speed up reforms' - including finance and the further liberalization of the control of the interest rates and the exchange rate (2010: 21).

The crisis provided a convincing suggestion that the 'old' model of the export-driven economy provided a risk in times of external crises ${ }^{7}$ and expedited the need for domestic reform; this structural reform could only be achieved by a supportive banking sector that would change its path-dependent lending pattern of favouring ailing SOEs and implicitly accept the rise of new forms of enterprise financing. Therefore, this article is focused on the latter.

\section{The GFC, China's Response and its Effects on China's Banking Sector}

In the years prior to 2007, China's economy had made a giant step. The Asian financial crisis of 1997 triggered decisive reforms by the Chinese government (Yang 2010). ${ }^{8}$ The WTO entry marked the start of a period of tremendous increases in the PRC's external trade, unleashing pro- 
tracted double-digit GDP growth. This filled the coffers of the Ministry of Finance with external reserves and propped up the sovereign's balance sheet enough to finance another round of recapitalization of China's largest banks. So when the GFC broke out, Chinese banks were in a relatively healthy state, with low NPL ratios and, due to the insulated nature of China's banking sector, this situation did not change much. Income was sound and stable as a result of continued financial repression through regulated interest rates. However, the structural and comparative lack of fee income underlined the overall lack of breadth of China's financial markets. Financing was still predominantly bank financing, and banks continued to foster lending in support of the fixed asset investment-led growth model. Exports grew in absolute size, but as a share of GDP, the contribution remained largely constant. To avoid instability from overly rapid reform, yet to activate the growth potential of financial innovation, China's leadership decided to continue on a cautious reform path. This entailed the introduction of ambitious objectives followed by careful, smaller reform initiatives 'with more caution and a renewed emphasis on the role of the state as owner of strategic facilities, provider of social services, market regulator and promoter of regional equality' (Bottelier 2010: 71).

The 2008 macro-economic stimulus programme combined loose monetary policies, massive state investments and state-guided increases in bank lending. It brought to the fore key structural features of China's financial system and its growth model. Lower levels of government showed significant resistance to central policies, as their own incentives were not necessarily aligned with the priorities of the leadership. Though the latter has a greater focus on the overall sustainability of growth, the former's horizon for the evaluation of policy consequences is far shorter. This led to a trade-off between short-term performance at the expense of long term sustainability (Bergsten et al 2009; Gordon \& Li 2011; Green 2013). Research has highlighted the 'frenzied implementation' of the stimulus programme (Naughton 2009; ${ }^{9}$ Goodstadt 2014:10 Wong 2011), which resulted in a too rapid selection of programmes that could receive funds during this phase. The banks continued to follow policy guidance in their lending decisions, lacking working independent credit evaluation mechanisms. In addition, repayment risks were neglected at the expense of future asset quality risk. The fact that the banks were ordered to lend, however, transferred the responsibility for future bad loans resulting from this hasty decision-making to the government. 
The credit bulge created its own problems in that it fostered an overheating of the property sector and added to the aforementioned problems with local government debt for banks. In a famed speech of 2011, CBRC Chair Liu Minkang informed his audience about the predicament for the Chinese banking sector and the banking regulator: they had a dual role to play, both in strengthening their own functioning and in taking their role and responsibility in the economic reform of the country. He noted the positive developments in the banking sector around cost control, income diversification (a greater share of fee and commission income) and an improvement in risk management causing a sharp reduction in NPL. But in the same speech, Liu made provisions for the fact that the 'software' of the banks still required improvement. Due diligence, client selection, adequate product pricing, risk data collection and problem solving were areas that would need to improve (Liu Minkang 2011). ${ }^{11}$ These shortcomings played a crucial role in the changes in the banking sector, which took place in the aftermath of the GFC.

\section{Changes in China's Banking Sector}

Both the GFC itself and the policy response of the central government changed the institutional environment for China's banking sector. The institutional deficits of the Leninist regulatory state and the consequences of the policies of financial repression triggered new policies as well as bottom-up processes of entrepreneurialism. The GFC pushed the Chinese leadership to the centre stage of global crisis management and global economic governance reform. While the Chinese leadership hesitated and sought to gain time to properly redevelop its policies according to the changing global context, there was little doubt that realizing a greater role for China in the global economy required financial liberalization. Financial liberalization is a prerequisite for the establishment of the RMB as a reserve currency, for finding new markets for Chinese brands and products, and for lessening the reliance on an export driven growth model. China's biggest banks grew to become some of the largest lenders in the world, and in spite of political restrictions set by the national government they intensified their international activities. At home, the stimulus programme triggered an explosive credit growth that led to a shift in lending patterns partly stimulated by the rise of shadow finance, which turned out to exert substantial innovative pressures on the banking industry. 


\section{Top-down Internationalization through 'Going Global'}

The strategy to 'Go Global' (literally 'Going out-Strategy') was first announced in 2001. It was the logical consequence of the economic reforms initiated in the 1970s (Zheng 2006) ${ }^{12}$ and complemented the Chinese attempts towards 'bringing in' foreign investment by urging Chinese enterprises to 'go out' (Jiang 2002). ${ }^{13}$ The GFC presented 'Chinese enterprises with a rare opportunity to go global,' as the People's Daily ${ }^{14}$ noted, citing a divergence in economic trajectory between a declining US economy and a thriving Chinese one.

In 2009, the CBRC reported that ' 5 large commercial banks have set up 86 branches or subsidiaries outside of China and acquired or invested in 5 foreign banks' with the goal to 'meet the needs of Chinese enterprises for cross-border financial services' and to 'tap the opportunities provided by international financial markets' (CBRC 2009: 40). ${ }^{15}$ Development banks had a prominent role in this process, especially the China Development Bank's (CDB). The CDB developed new business areas at home and abroad by offering new products to China's local authorities and by pushing overseas activities of Chinese companies. While a stateowned policy-bank, it actively sought to change its existing business model after the GFC (Walter \& Howie 2011). CDB's most prominent direct foreign investment in the financial services industry has been its tie-up with UK's Barclay's bank, linked in 2007 and extended in 2014. Starting as a means for strategic cooperation in Africa (Helgren 2014) ${ }^{16}$ the cooperation soon extended when CDB sought to benefit from Barclay's experience in the commodities business. CDB invested directly in Barclay's and stated that this investment should also help it further in their commercialization drive. Together with China Export Import Bank (C-EXIM), CDB was initially the most prominent Chinese lender going abroad. The two policy banks were complemented by the state-owned commercial banks to actively increase their overseas exposures. While the move abroad was in line with the central strategy, CDB's domestic moves were more controversial and contributed to the drastic rise in local authority debt (see below).

The policy banks were followed by a number of Chinese commercial banks in the period after the GFC. ICBC acquired or took a stake in the US business of the Bank of East Asia, Thai lender ACL, a stake in the Argentinian business of Standard Bank, Tekstil Bankasi in Turkey, and it set up a branch in Brazil. China Construction Bank also set up in Brazil through an acquisition of BicBanco and further increased its international 
footprint by investing in Russian VTB following the creation of a Russian subsidiary. Notably, it was not just the state-owned commercial banks that invested outside of China. Bank of Communications invested in Brazilian lender Banco BBM in a deal that was announced following a high-profile trip of Premier Li Keqiang to Latin America. ${ }^{17}$

In sum, while the Go Global strategy was coined before the GFC, both the improved opportunities for doing business abroad and the need to support industrial corporations facilitated more international activities by Chinese banks. While state guidance and direct involvement played a substantial role, increased international presence adds further pressure on the leadership to continue and intensify reforms. A growing number of Chinese banks accused of money laundering face legal proceedings, pushing the state to speed up the process of legislative and regulatory reform at home (PBOC 2015a).

The intensification of the strategy would also play into concrete measures to internationalize the Chinese currency. The gradual establishment of the RMB as an international currency thus reflects both a market-driven process and an explicit policy objective of the Chinese leadership (Eichengreen \& Kawai 2014: 5). China's policy response to the crisis created the opportunity to internationalize the RMB, which, in turn, increased pressure on China to continue reform and opening up, particularly in its financial system (Xinhua 2016). ${ }^{18}$

\section{Top-down Credit Growth and Shifts in Lending Behaviour}

With the implementation of the stimulus programme came a marked shift in banks' lending behaviour. One of the main points of criticism about the weak economic role that banks play in the Chinese economy is that they have a lending bias. Difficulty in obtaining formal financing has been identified as a great obstacle to the development of smaller private enterprises. Nee and Opper describe the fundamental lending bias of Chinese banks, stating that at the outset of the GFC, 'it is commonplace for even established medium and large sized private firms to be denied access to credit from commercial banks' (2012: 97). Since the 1980s and 1990s, banks have allocated credit to more of the profitable SOEs than did the government. These were more likely to be given to SOEs that adopted reforms, which acted as signals of good performance. Later in the 1990s, the link between bank loans and enterprise profitability grew weaker as the government shifted bail-out responsibilities to banks' (Cull 
$\& X u$ 2003: 534). Chinese banks started to bear greater responsibility for the performance of their creditors, yet the piling up of NPL demonstrates that banks were not able to handle this responsibility.

A lack of profit incentives on the side of banks due to prevalent state ownership, project selection being subject to informal and networkbased procedures, as selection of 'bankable projects' was subject to collateral requirements, as well as personal relations, all contributed to these difficulties (Gregory \& Tenev 2001) ${ }^{19}$ On the side of the companies, the relative opacity of private firms is seen as the main reason why companies find it harder to obtain credit. A wave of commercialization efforts later, Hale and Long (2010) still found that SOEs have easier access to formal credit and to trade credit. As a consequence of the constraints for bank lending shadow banking grew in significance. Hale and Long observed that:

Chinese private firms have resorted to a variety of mechanisms [...] these mechanisms include a greater reliance on retained earnings (via lower tax rate and higher profit rate), a flexible yet reasonably efficient usage of informal finances, and very efficient management of working capital. (2010:14)

This situation changed with the GFC. In the period from 2009 to 2012, the share of bank loans to private enterprises rose from 26 per cent to 52 per cent amidst an unusually sharp growth in credit (Borst \& Lardy $2015)^{20}$ indicating an increasing commercial orientation by Chinese banks. ${ }^{21}$ Noting the reliance of privately owned companies on informal financing, the rise of shadow banking may well have helped to channel financial funds to more dynamic SMEs, laying a foundation for a more broad-based economic development that relies to a lesser extent on fixed asset investment. Lardy notes that the number of private enterprises grew between 2008 and 2012 from 6.6 million to 10.9 million. These companies were also better able to secure bank loans: their share in total loans climbed from 13.04 per cent to 16.37 per cent according to official PBOC statistics (PBOC 2015a). The lending data includes only official bank lending, and given the simultaneous emergence of informal lending or lending that may not be accurately reflected in the statistics, it is reasonable to assume that this period indeed witnessed a growth of the private sector, supported by improved credit access for the private sector. The composition of leverage underwent a similar change after the crisis. Leverage has gone up in certain sectors, but has come down since the GFC for private enterprises. The highest leverage post-GFC is seen with real estate and construction firms. Similarly, where borrowing costs were higher for private enterprises before the GFC (as compared to 
SOEs), this difference vanished after the crisis. The study did, however, find that borrowing costs for construction and real estate companies declined, whether privately owned or SOEs (Chivakul \& Lam 2015).

By 2015, as much as 45 per cent of Chinese debt was related to real estate. This data further supports the assertion that the traditional lending bias is changing; there is less ownership-based bias, and more industry bias. Retained earnings remains an important source of financing for the private sector, even though it manages to increasingly secure formal financing from the commercial banks. However, real estate and construction are the sectors that remain credit-hungry, and the banks remain willing to lend to these industries, perhaps also because of their pivotal importance for the broader economy, and in light of the commitment of authorities to ensure an orderly winding down of the property boom.

In sum, the lending behaviour of the banking sector changed after the GFC. First, it displayed improved credit access for private companies; at the same time, there was a strong sectoral bias in lending - construction and real estate - that fuelled a boom in investment and property construction. The share of formal credit, however, does still not reflect the size and especially the contribution to overall profits of the private sector to China's economy. Though improvements can be witnessed on an incremental scale, evidence for a lending bias still exists. In response to this the 3rd Plenum of the 11th Central Committee in 2013 made the case for increased reform in the financial sector, giving more room for privately-owned banks to foster healthy competition. Yet implementation of these policies started slowly, leading to ten private banking licenses being initially handed out by the CBRC in 2014 and the transition to a normal licensing system that awarded a total of 17 licenses until 2017 (CBRC 2017). ${ }^{22}$ Yet the real institutional changes happened outside the regulatory framework.

\section{Bottom-up Changes: The Rise of Shadow Banking}

With the official financial system under tight state control and the policy of financial repression firmly in place, investors, local authorities and private savers alike intensified their search for alternative products and services. Shadow banking activities have expanded greatly during the first years of implementation of the stimulus programme between 20082010. Standard \& Poor's estimated in 2013 that the size of China's shadow banking came out at RMB 22.9 trillion (USD 3.7 trillion), equivalent to 
34 per cent of total loans and 44 per cent of the PRC's 2012 GDP. This stands in stark contrast for instance to the G20 and Eurozone countries, where shadow banking is estimated to total 111 per cent of 2011 GDP. Thus it is not so much the size of China's shadow banking sector, but its rampant growth that causes concern. However, some other sources put the Chinese figure at around the size of GDP (Wei et al. 2014). ${ }^{23}$ By 2017, shadow banking is estimated to have reached USD 8.5 trillion, accounting for nearly 16 per cent of corporate finance in China (Bloomberg 2017) ${ }^{24}$ It is also not just the size of exposure, but also the growth rate and composition, that are potential sources of problems. It is critical to note that it had the potential to destabilize a core component of the banking system, i.e. the stickiness of client deposits, as these deposits could now be mobilised in a search for greater yield. The main products that make up shadow banking are wealth management products, trust and entrusted loans, and underground financing or banking, which is the practice engaged in by loan sharks, pawn shops, and informal lenders outside of the regulated banking sector. Charlene $\mathrm{Chu}$, an analyst of Fitch Ratings gained substantial fame by underlining the liquidity risk that this posed, as short-term WMP were used to fund long-term loan commitments. ${ }^{25}$ This triggered in a spike in interbank activity, especially in June 2013 when the PBOC engineered a sharp signal to banks that they were walking a very tight rope. Because of their better position in obtaining client deposits, the large State-Owned Commercial Banks were large net lenders in the interbank market. ${ }^{26}$

The authorities started to use the measure of total social financing to differentiate between credit extended by banks and other sources of debt financing. The gap between the two measures started to grow sharply after 2010, in evidence that alternative financing sources started to make up a growing percentage of financing for companies that could not be met by the banks by means of traditional lending.

At the same time, the bigger part of shadow banking has served the credit expansion to sectors of which the regulators sought to limit indebtedness. The demand for alternative venues to obtain credit included local governments who used non-banking sources for 43 per cent of their debts of 17.9trn RMB (June 2013) with 11 per cent by shadow banks, according to the China National Audit Office (Wei et al. 2014). Stricter reserve requirements and interest rate controls invited both public and private actors to seek innovative products outside the established system. Thus, commercial banks as well as local government entities and state-controlled corporations - all of them with relatively easy access to 
TABLE 1: Total Social Financing and RMB Credits

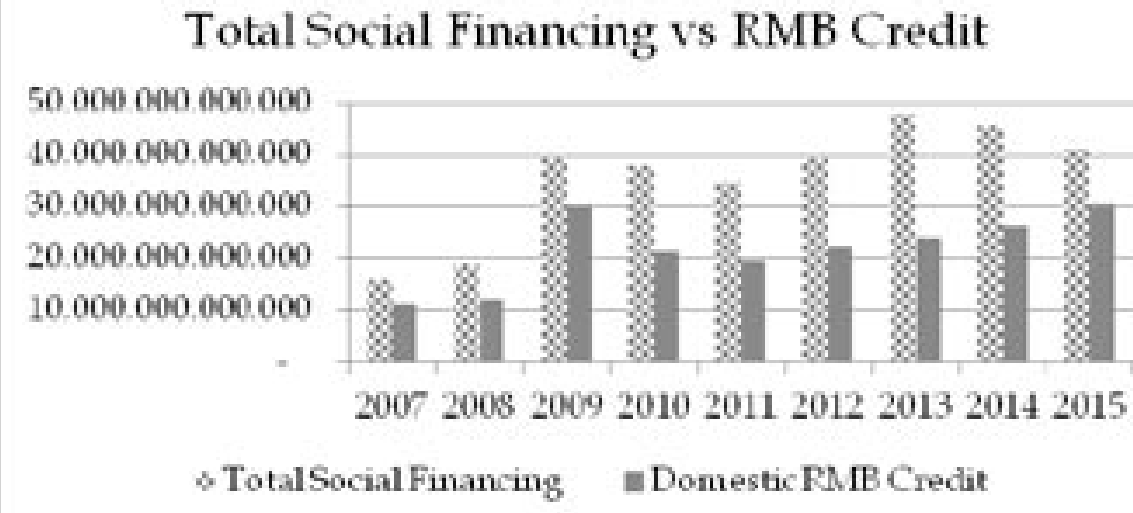

Source: Reuters, EIKON

the formal funding - expanded their shadow banking activities in the context of the stimulus program. Banks, due to the strict regulation on the loan to deposit ratio, discovered in it a means to increase lending by putting the exposures off balance sheet, satisfying, by means of WMP, the demand of savers for higher yields. China Development Bank played a crucial role in developing these alternative models of local funding later copied by more Chinese banks (Walter and Howie 2011). Furthermore, state-controlled enterprises and local state entities have utilized their facilitated access to formal credit to provide loan guarantees for private businesses and real estate developers. These guarantees were in turn collateralized as wealth-management products.

Banks also developed innovative ways to work around regulation, hiding their exposure by cooperating with specialized vehicles or accounting for risky debt as investments. China's mid-tier banks in particular turned increasingly towards 'complex instruments to make new loans and restructure existing loans that are then shown as low-risk investments on their balance sheets, masking the scale and risks of their lending to China's slowing economy' (Zhang \& Miller 2016) ${ }^{27}$ Even after trade in some of the products was banned from the banks balance sheets in 2014, they soon reappeared under a different heading, thus indicating the ongoing race between the industry and the regulators. Banks even started to operate as trustees in lending between non-financial firms and financial firms. These 'entrusted loans' played a crucial part in offsetting the impact of the decline in official bank lending and in the rise of shadow banking (Chen et al. 2016) and meeting the demand of borrowers for liquidity due to persistent mismatches between short- 
term borrowing and long-term repayment capacity (Moody's 2013). This dual assessment - that on the one hand, shadow banking met legitimate borrowing needs, but on the other hand posed a systemic risk - was recognized in a Circular regarding the Regulation of Shadow Banking (Guowuyuan 2013), ${ }^{28}$ which lay out the premises for the tightening of regulation in 2014, making the effort to rein in and gain control a challenging balancing act.

The growth in shadow finance raised the alarm in Beijing and thus necessitated a multi-faceted response, combining efforts to address the funding needs of local authorities with regulatory innovations to increase the oversight of non-bank financial institutions. The emergence of shadow banking therefore highlights the growing competitive pressures on China's banking industry outside the traditional market framework and the increasing acceptance of new providers of banking services by the PRC's leadership. As Chen et al. (2016) suggest, this can not be explained solely by the fact that the state-owned banks under Central Huijin are under more direct state-control and thus stricter in following regulatory guidance. Indeed, financial innovation was not necessarily seen as negative by the highest state officials: Premier Li Keqiang (2015: 4$)^{29}$ identified innovation and entrepreneurialism as key drivers for future growth; and shadow finance generated both entrepreneurialism and innovation by, among other things, linking e-commerce with financial services.

As the previous discussion has already indicated, the expansion of shadow banking activities has, on the one hand, created new financialized uses of capital predominantly for the capital-intensive statecontrolled sector and, on the other hand, has created new financial sources for the labour-intensive private sector. While the private sector is notoriously underbanked, the state controlled sector is now lending to the private sector outside the regulated commercial banking sector. What is more, shadow banking further facilitated the rise of internet finance, which has given unprecedented stimulus to changes in the banking sector.

\section{Bottom-up Innovation: The Rise of Internet Finance}

Internet finance in China experienced an enormous, even wild, development highlighting numerous regulatory shortcomings and conflicts (Zheng 2016)..$^{30}$ A case in point is internet-based P2P (peer-to-peer) lending (Tsai 2015: 70-72). Early concerns regarding the risk of the P2P 
development in China ${ }^{31}$ were substantiated in 2016 when 21 people were detained over the breakdown of the Ezubo platform in $2016 .{ }^{32}$ The total number of P2P-firms was estimated at 3800 with an annual capital volume of around US $\$ 21 \mathrm{bn}(\mathrm{Su} 2016)^{33}$ before the government de facto imposed a freeze on the establishment of new ones in April 2016 (Wu 2016). ${ }^{34}$ While P2P-lending propelled innovation and growth, it created substantial political and social risks much to the concern of Chinese authorities. With more than 1200 P2P lending platforms in trouble or suspected of cheating ( $\mathrm{Su} 2016$ ) the authorities feared the loss of 'hundreds of billions of yuan from retail investors'.

China provided a very specific soil for the growth of internet finance: while Big Data has become a global mega-trend including the PRC, financial repression led to a mismatch between demand and supply in China's financial sector. Particularly 'demand for financial services of ordinary people and many small and medium-sized companies has still not been met'. ${ }^{35}$ Second, the use of smartphones and online platforms is extremely popular in China with more than 600 million smart-phone users and more than 200 million users of WeChat and Sina Weibo; and the size of the country and its population is a huge incentive to develop financial services that 'will no longer be subject to the restraints of time and space' (Huang 2015). Thus, internet finance offers the promise of inclusive finance for all kinds of customers and investors (Ping et al. 2016: 6).

This sudden rise of internet finance in China was driven by two major developments: successful e-commerce triggered a move of online-traders into financial services while at the same time traditional financial services providers increased their online business (Takeshi 2014: 1). For example, internet trading giant Alibaba allowed users of AliPay to invest money left on their accounts into money market funds offered by $\mathrm{Yu} \mathrm{E}$ Bao, thus offering private wealth products outside the traditional banking sector. Those investments were then channelled into an investment fund, which soon grew to become the largest such fund in China reaching 250bn RMB in January 2014. In 2015, Alibaba extended its online financial activities and established Mybank.

Following Alibaba's success, numerous companies of different sectors - internet, communication, insurance - created similar and linked offers. In 2015, China's gaming and social network giant Tencent Holdings launched the PRC's first online-only bank, We Bank. ${ }^{36}$ Prime Minister Li Keqiang attended the opening of We Bank and emphasized the role of these new internet banks in providing credit to small and medium 
size enterprises. While internet finance was seen as generally positive, the leadership also emphasized the need to control internet activity and reminded the companies of their responsibility to prevent the spread of incorrect information and activities. Internet finance thus became caught between ambitious plans to foster innovation in China and the imperative to tighten control of information and public discourse (Dong 2016; Xing 2016). ${ }^{37}$

When the PBOC, together with the CSRC, finally published guidelines for online banking services in June 2015, P2P lending in China had already grown into the largest P2P-market in the world. For the month of May 2015, P2P-lending was estimated to have reached USD $10 \mathrm{bn}$. Regulators were pushed hard to find a balance between supporting Premier Li Keqiang's internet plus strategy and getting their hands on stock market speculation, further fuelled by funds borrowed online via China's booming internet platforms. The guidelines published by the PBOC contained both policy measures to encourage innovation and regulatory propositions to establish effective supervision. A set of restrictive regulations was announced in the beginning of 2016, offering much-awaited rules for the surging sector. ${ }^{38}$ These rules allowed money market funds among other to invest in negotiable certificates of deposits and corporate bonds. The authorities faced an important dilemma in how to approach regulating the new investment opportunities. Following the correction in the stock market that occurred in mid-2015, and an environment where authorities attempt to stem outflows of money from the country to support the USD/RMB exchange rate, another source for higher yield that keeps investors' money in the country was extremely welcome.

The political difficulties in defining the official policy for the regulation of internet finance can easily be deducted from the number of organizations involved: the People's Bank of China, the Ministry of Industry and Information, the Ministry of Public Security, the Ministry of Finance, the State Administration for Industry and Commerce, the Legislative Affairs Office, the China Banking Regulatory Commission, the China Securities Regulatory Commission, the China Insurance Regulatory Commission and the State Internet Information Office (Wood \& Wang 2015). ${ }^{39}$ Regulatory principles needed to be defined as well as regulatory responsibilities to allow for dynamic development while containing social and political risks (PBOC 2015b: 2).$^{40}$ Finally, the authorities ordered the establishment of a self-regulatory body, the National Internet Finance Association of China (Zhongguo hulianwang Jinrong Xiehui) in Shanghai, 
and the formations of regulatory teams to deal with high-profile cases of internet finance fraud in the main municipalities (Wu et al. 2016). ${ }^{41}$

Most of the big banks had first sought to block the rise of internet finance, but some, like Minsheng Bank, early on cooperated with Alibaba's online financial services. In a reaction to the growing popularity, the PRC's biggest banks announced free mobile transfers up to 5000 RMB. They followed the example of China Merchants Bank and other regional banks that had taken the same step in 2015. The 'Big 5' banks followed a rule from the PBOC, which had 'issued a notice in December requesting financial institutions to scrap online and mobile transfer fees following the surge in growth of internet payments services such as Alibaba-backed Alipay and Tencent's WeChat Pay. ${ }^{42}$ While Alipay kept its free transfer policy, Tencent announced plans to introduce a small fee for mobile transfers to private accounts in order to cover its own costs indicating that the big online companies had cross-subsidized the introduction of internet financial services beforehand.

In sum, the reaction of China's traditional banks to their new competitors entailed a combination of trying to stymy their growth by lobbying the central government to create mechanisms of control and regulation while at the same joining key players in their business development. The emergence of new and innovative competitors has already started to change the business sectors. The new competitive pressures in China's banks promise to push for some long-awaited changes in governance, management and products. Thus one of the key factors pushing for change in the PRC's banking sector emerged outside of both the official policy and the official regulatory framework.

\section{Conclusion}

When the GFC hit the PRC, the country's tightly controlled financial system looked healthy and resilient. With the credit binge following the macro-economic stimulus programme of 2008, China's banking sector suddenly found itself in the middle of a profound transformation: seeking to strengthen its presence abroad, it suddenly faced strong, new and widely unregulated competition from shadow finance. On the one hand, this met the demand of savers for more yield and satisfied underserved borrowers' demand for credit helping to finance the economic restructuring away from an export model, but it posed an increasing systemic risk to which the regulatory institutions were not necessarily equipped, both in organization and tools, to answer. With 
patterns of lending shifting and internet finance driving innovation, the banks needed to react. One key element of their reaction has been their continued lobbying for political protection. With the regulation of April 2016 following cases of massive fraud, internet finance is undergoing a period of scrutiny and supervision. Yet by introducing new regulations, the Chinese authorities have publicly acknowledged the positive contribution of new financial competition and their significance for the Chinese economy. The traditional lenders enjoyed an easy environment as a result of regulated interest rates, making as much as US\$ 228 billion in net profit in the record year 2013 (Bloomberg 2013) and the rise in WMPs certainly added to their increased share of fee-based income. ${ }^{43}$

China's banking industry is quickly changing. Though banks have been instructed to increase lending to SMEs (not necessarily privately owned) and private firms, they find it hard to adjust and look for ways to continue lending to their more traditional borrowers: state-owned companies, real estate developers and local governments (Sweeney \& Wildau 2013), ${ }^{44}$ but often try to conceal these exposures, making the flow of funds more opaque and thus making it harder for the regulators to keep track of systemic risk building up. As more opportunities unfold for investors to get higher yields on a range of financial products, banks will likely see their deposit bases erode and competition for savings intensify. There are two cases in point: the emergence of shadow banking and the rise of money market funds.

The new financing and investment opportunities broadly support an active policy that seeks a greater role of SMEs and private firms, moving away from manufacturing for export, but rather supporting a more dynamic and innovative domestic economy that relies more on domestic consumption rather than investment. This has had the result that regulators do not necessarily step in to choke off new investment opportunities, although they do remain vigilant about the systemic risk. The regulators will have to balance complex considerations, such as supporting the economic restructuring, keeping a watchful eye on the micro-prudential environment (not weakening the existing banks too much) and ensuring a redirection of investment funds in a way that does not endanger financial stability.

They have also clarified that the speed with which the necessary reforms will be enacted will depend on a favourable macro-economic environment. Of equal importance is the need to strengthen intra-agency coordination between the various regulators to avoid a build-up of systemic risk resulting from increased inter-linkages between the various 
sectors in the financial sector: insurance, trust companies, banks, and challengers such as internet funds are increasingly connected due to financial innovation as outlined in this paper. This increases systemic risk, but the regulators are still organized in sectoral silos (though there are persistent rumours that this will change in the very near future).

The response to the GFC, in the form of a massive and only partly planned stimulus, created its own problems. Firstly, local governments increased land sales, largely to property developers, who in turn started a building spree that many say is featured by an inefficient distribution: ghost towns in some places, bubbles in others. Secondly, the professionalization of banks was reversed ${ }^{45}$ and may have helped in spurring the tremendous surge in shadow banking. In addition, this response took place in the context of an environment of unfinished banking reforms, which has led to a steady build-up of financial vulnerabilities. The saturation of the domestic credit market has sped up the Go Global strategy of Chinese enterprises, and has also proven to be an impetus to an outward opening of China's financial sector: the project of RMB internationalization, relying on a phased opening of the capital account and a market-determined exchange rate are now being pursued with more vigour than ever before. This means however, that the Chinese economy has become more important as a potential source of risk to the rest of the world, while the developments also rattled the balance of power between the regulators of the financial sector.

The absence of clear and comprehensive government policies on developments in the financial sector created a vacuum that was being filled in an entrepreneurial fashion by market participants. This puts the regulators on the defensive and, where it concerns cross-mandate issues, leads to intense debate about the responsibilities of each individual regulatory institution. But the race between entrepreneurial innovators and regulators is set to continue, and it promises a dynamic institutional framework for China's banking industry.

Michiel Haasbroek is a political scientist and financial analyst affiliated with the Ruhr University Bochum, Department of East Asian Politics. He works in China on issues of financial regulation. Email: michiel.haasbroek@outlook.com

Jörn-Carsten Gottwald is Professor of East Asian Politics at Ruhr University Bochum in Germany. He works on China's political economy, the regulation of financial services in China and Europe and China's new role in global economic governance. Email: joern-carsten.gottwald@rub.de 


\section{NOTES}

1 Zhou Xiaochuan 2015. 'Zhongguo jinrong gaige he fazhan licheng huigu'. The Paper: Zhou Xiaochuan wan zi chang wen xiangshu zhongguo jinrong gaige: bei dan'ge de yao jishi buke. 1 October 2015. Available at http://www.thepaper.cn/newsDetail_forward_1381206. Accessed 2 March 2017.

2 Martin, Michael F. 2012. China's Banking System: Issues for Congress. Washington: Congress Research Service. https://www.fas.org/sgp/crs/row/R42380.pdf. Accessed 1 March 2016.

3 Lardy, Nicholas R. 2008. Financial Repression in China. Peterson Institute for International Economics, Policy Paper 08-08, downloaded from: https:/ / piie.com/ publications/policy-briefs/financial-repression-china. Accessed 26 April 2017.

4 Wen Jiabao 2010. Report on the Work of the Government. Delivered at the Third Session of the Eleventh National People's Congress, 5 March 2010, http:/ / english. qstheory.cn/resources/work_reports/201109/t20110920_111464.htm. Accessed 10 March 2017.

5 Dai Xianglong 2011. Tuijin guoji jinrong wending yu zhongguo jinrong gaige', Jinrong Shijie, 19 April 2011, http://www.xinhua08.com/opinion/jrsj/2011/issue11/201104/t20110419_471668.html. Accessed 20 February 2017.

6 Caixin 2008. 'Yinhangjia lunyun: Jinrong fengtaixia zhongguo yinhangye gaige zhi lu'. Caixin, 3 November 2008, available at http:/ / finance.qq.com/a/20081103/002221. htm. Accessed 20 January 2017.

7 The value of exports dropped from a end-September 2008 peak of RMB 408trn in by 40 per cent to a low at end of March 2009 of RMB 245 trn (Data: National Bureau of Statistics).

8 Yang Zaiping 2010. 'Hou weiji shidai zhongguo yinhangye anquanxing wenti sikao'. Zhongguo Xinxi Baoshe, 14 January 2010, available at http:/ / www.stats.gov. cn/tjzs/tjsj/tjcb/zggqgl/201001/t20100114_37680.htm.

9 Naughton, Barry 2009. 'The Scramble to Maintain Growth'. China Leadership Monitor No. 27 (2009), http:/ / www.hoover.org/sites/default/files/uploads/documents/ CLM27BN.pdf. Accessed 26 April 2016.

10 Goodtstadt, Leo F. 2014. The Local Government Crisis: When China's Financial Management Faltered, HKIMR Working Paper No. 27-2014, http://www.hkimr. org/uploads/publication/399/wp-no-27_2014-final-.pdf. Accessed 22 April 2016.

11 Liu, Mingkang 2011. 'China's Financial Reform and Economic Development During the 12th 5-year Period - Speech by CBRC Chairman Liu Mingkang at Lujiazui Forum', http://www.cbrc.gov.cn/EngdocView.do?docID=201106134F7B8902E3B AC6C5FFA807B15F8A0E00. Accessed 22 April 2016.

12 Zheng Yongnian 2006. 'Zhonguo 'Zouchuqu' shoudao Xifang zulan, in Huanqiu Shibao, 26 June 2006; http://news.xinhuanet.com/world/2006-06/24/content_ 4741860.htm. Accessed 10 June 2009.

13 Jiang, Zemin 2002. Report to the 16th Party Congress, http:/ / www.china.org.cn/english/features/49007.htm. Accessed 10 August 2015.

14 People's Daily Online, 'Chinese Enterprises should better prepare for integration', 4 June 2009. Available at http:/ / english.peopledaily.com.cn/90001/90778/90857/ 90861/6671939.htm. Accessed 10 June 2009.

15 China Banking Regulatory Commission 2009, Annual Report 2009. Part two: Banking reform \& opening-up. Available at http:/ / www.cbrc.gov.cn/EngdocView.do?docID =20110613FCE47ABD05FA4204FF5BCBC854991A00. Accessed 22 June 2012.

16 Helgren, Chris 2014, 'Barclays, China Development Bank extend strategic tie-up for Africa'. Reuters, 26 March 2014, available at http:/ / uk.reuters.com/article/uk-cdbafrica-idUKBREA2P08C20140326. Accessed 2 April 2016. 
17 Wildau, Gabriel 2015b. 'Tencent launches China's first online-only bank', in Financial Times online, 5 January 2015, https:/ / next.ft.com/content/ccc5a6dc-9488-11e4-82c700144feabdc0. Accessed 30 March 2016.

18 Xinhua 2016. 'Renminbi guojihua shi ru kuaichedao 101ge guojia zuowei maoyi huobi', in Renmin Ribao online, 5 November 2016. http://paper.people.com.cn/ rmrb/html/2016-11/05/nw.D110000renmrb_20161105_2-02.htm. Accessed 2 February 2017.

19 Gregory, Neil and Stoyan Tenev 2001, 'The Financing of Private Enterprise'. Finance and Development 38 (1), http://www.imf.org/external/pubs/ft/fandd/2001/03/ gregory.htm. Accessed 22 April 2016.

20 Borst, Nicholas and Nicholas Lardy 2015. Maintaining Financial Stability in the People's Republic of China During Financial Liberalization, Working Paper 15-4, Peterson Institute for International Economics. Available at http:/ / www.piie.com/publications/wp/wp15-4.pdf. Accessed 22 April 2016.

21 Credit growth exceeded 30\% in three consecutive quarters starting in Q2 2009, before normalising to a pre-crisis rate of around 15\% QoQ. (Data: National Bureau of Statistics)

22 China Banking Regulatory Commission 2017. 'CBRC Issued Guiding Opinions on Supervision of Private Banks', 6 January 2017. Available at http://www.cbrc.gov. cn/EngdocView.do?docID=BCCACFBE010548BBB2BCCFBA1A0F388E. Accessed 12 April 2017.

23 Wei, Lingling, Davies, B., Shen, Hong 2014. 'China tightens Grip on Shadow Banks. In WSJ online', 6 January 2014. http://online.wsj.com/news/articles/SB10001424 052702304887104579303732528192434 . Accessed 14 February 2014.

24 'China's \$8.5 Trillion Shadow Bank Industry is Back In Full Swing', Bloomberg News, 18 April 2017, https:/ / www.bloomberg.com/news/articles/2017-04-18/china-s-85-trillion-shadow-bank-industry-is-back-in-full-swing. Accessed 10 May 2017.

25 Wildau, Gabriel, Zhang, Shengnan 2013, 'In China, off-balance sheet lending risks lurk in the shadows. Reuters Online, 8 April 2013. http:/ / www.reuters.com/article/ us-china-banks-shadow-risk-idUSBRE93705F20130408. Accessed 30 March 2016.

26 It should be noted that lending in the interbank market is exempted from inclusion in the loan to deposit ratio.

27 Zhang, Shu and Matthew Miller 2016, 'Mid-tier Chinese banks piling up trillions of dollars in shadow loans', Reuters, 31 January 2016, http:/ / www.reuters.com/article/china-banks-investment-idUSL8N156063. Accessed 26 April 2016.

28 See Guowuyuan Bangongting 2013, 'Guanyu Jiaqing Yingzi Yinhang Jianguan Youguan Wenti de Tongzhi', http://www.pkulaw.cn/fulltext_form. aspx?Gid=264165\&Db=chl. Accessed 12 April 2017.

29 Keqiang, Li 2015. Zhengfu Gongzuo Baogao, 5 March 2015. Available at http:/ / www. gov.cn/guowuyuan/2015-03/16/content_2835101.htm. Accessed 12 April 2017.

30 Zheng Liansheng 2016. Zhongguo hulianwang jinrong de fengxian he jianguan xiankuang, in Cai Zhi Yanjiu, 20 January 2016. Available at http://pmi.caixin. com/2016-01-20/100901589.html. Accessed 3 April 2016.

31 Wang, Shenlu, Liu, Ran, and Yang, Lu 2014. 'P2P Lender Heading Into Dangerous Waters, Critics Say'. Caixin Online, 18 April 2014. Available at http:/ / english.caixin. com/2014-04-18/100667283.html. Accessed 8 February 2016.

32 Han, Yi 2016. 'Executives among those held over 50bln Yuan scam, Xinhua says', Caixin Online, 2 February 2016. http:/ / english.caixin.com/2016-02-02/100906456. html. Accessed 9 February 2016.

$33 \mathrm{Su}$, Edgar 2016. 'China says will step up regulation of internet finance'. Reuters, 23 January 2016, http://www.reuters.com/article/us-china-internet-regulations- 
idUSKCNOV10FD. Accessed 2 April 2016.

$34 \mathrm{Wu}$, Hongyuran 2016. 'What's in a Name? If It's 'P2P Lender', Gov't Says Don't Open'. Caixin Online, 21 April 2016, http:/ / english.caixin.com/2016-04-21/100935225.html. Accessed 26 April 2016.

35 Huang, Yiping 2015. 'China is fertile ground for growing internet finance'. Caixin online. 16 April 2015, http://english.caixin.com/2015-04-16/100800919.html. Accessed 29 April 2016.

36 Wildau, Gabriel 2015a. 'China's BoCOM acquires Brazil's Banco BBM', Financial Times, 5 February 2015, http://www.ft.com/intl/cms/s/0/77c99598-feb5-11e484b2-00144feabdc0.html\#axzz450Wd201M. Accessed 22 April 2016.

37 Xing Shiwei 2016. 'Zhongyang zhengfawei: tuidong hulianwang jinring guifan he jianguan'. Xin Jing Bao, 22 January 2016; Dong, Ximiao 2016, '2016 jiangcheng hulianwang jinrong guifan fazhan nian'. Xinlang Caijing Jinrong Guancha, 27 January 2016. Available at http:/ / finance.sina.com.cn/zl/bank/2016-01-27/zl-ifxnuvxc2092515. shtml. Accessed 1 April 2016.

38 Pozen, Robert, and Teresa Hamacher 2014. 'Surge in China internet money funds is risky', in Financial Times online, 6 April 2014. Available at https:/ / next.ft.com/content/a1a3eea6-b9ae-11e3-957a-00144feabdc0. Accessed 27 April 2016.

39 Wood, Ian and Davies Wang 2015. 'The People's Bank of China recently issued guidelines on providing financial services on the internet in China', China Digest - Internet Finance Update, 2 September 2015. Available at http://www.elexica. com/en/legal-topics/banking/02-china-digest-internet-finance-update. Accessed 2 April 2016.

40 People's Bank of China 2015b. 'Guanyu cujin hulianwang jinrong jiankang fazhan de lingdao yijian', 18 July 2015, http:/ / finance.people.com.cn/money/n/2015/0718/ c42877-27324335.html. Accessed 2 April 2016.

41 Wendy $\mathrm{Wu}$, Jun Mai, Zhou Xin 2016. 'Unrest risk from internet financial fraud rise', South China Morning Post, 29 February 2016. http:/ / www.scmp.com/news/china/ economy/article/1904346/unrest-risk-internet-financial-fraud-rise. Accessed 28 July 2017.

42 Zen Soo 2016. 'Mainland China's top 5 banks waive charges for money transfers as competition from internet finance companies heats up'. South China Morning Post, 25 February 2016. http://www.scmp.com/business/banking-finance/article/1916728/mainland-chinas-top-five-banks-waive-charges-money. Accessed 12 April 2017.

43 ICBC's fee and commission income grew from $22 \%$ in 2009 to $28 \%$ in 2011 . For $\mathrm{CCB}$, another lender active in issuing WMP, it grew from $23 \%$ to $29 \%$ in the same period.

44 Sweeney, Pete \& Gabriel Wildau 2013. 'Analysis: Forced lending to China SMEs may risk more harm than good', Reuters, 19 November 2013 http:/ / www.reuters. com/article/us-china-smallbusiness-analysis-idUSBRE9AI08V20131119. Accessed 22 April 2016.

45 In various circulars to banks, the CBRC has also drawn attention to cases of fraud around WMP issuance, highlighting the immense tasks to create an adequate internal control environment, as such cases involved offering products that are not officially sanctioned by the banks themselves. 


\section{REFERENCES}

Andreosso-O'Callaghan, Bernadette and Jörn-Carsten Gottwald 2013. 'How red is China's red capitalism? Continuity and change in China's financial services sector during the global crisis'. Asia Pacific Business Review 19(4): 444-460.

Bergsten, C. Fred, Charles Freeman, Nicholas R. Lardy, and David J. Mitchell 2010. China's Rise: Challenges and Opportunities. Washington D.C.: Center for Strategic and International Studies.

Bottelier, Pieter 2010. 'China and the International Financial Crisis'. In A. Marble and T. Tanner (eds), Strategic Asia 2009-2010. Washington D.C.: The National Bureau of Asian Research.

Chen, Kaiji, Ren, Jue. and Zha, Tao 2016. 'Unintended consequences of monetary and regulatory policies on banks' risk-taking behaviour: A closer examination of China's shadow banking'. NBER Working Paper 21890. January 2016.

Chivakul, Mali, and W. Raphael Lam 2015. Assessing China's Corporate Sector Vulnerabilities. Working Paper No. 15/72. Washington: International Monetary Fund.

Collins, Neil and Jörn-Carsten Gottwald 2014. 'Market Creation with Leninist Means: the Party-State, Private Authority and the Regulation of Financial Services in the People's Republic of China'. Asian Studies Review 38(4): 620-638.

Cull, Robert and Lixin Collin Xu 2003. 'Who gets credit? The behavior of bureaucrats and state banks in allocating credit to Chinese state-owned enterprises'. Journal of Development Economics 71(2003): 533-559.

Eichengreen, Barry and Masahiro Kawai 2014. 'Issues for Renminbi Internationalization: An Overview'. Tokyo: ADBI Working Paper Series.

Farrell, Henry and Newman, Abraham L. 2010. 'Making Global Markets: Historical Institutionalism in International Political Economy'. Review of International Political Economy 17(4): 609-638.

Gordon, Roger H. and Wei Li 2011. Provincial and Local Governments in China: Fiscal Institutions and Government Behavior. Washington: National Bureau of Economic Research Working Paper 16694.

Gottwald, Jörn-Carsten 2012. 'Regulating Financial Services in the EU: A Case of Successful Institutional Learning'. In H. Zimmermann and A. Duer (eds.), Key Controversies in European Integration. London: Palgrave MacMillan 2012: 131-137.

Gottwald, Jörn-Carsten and Neil Collins 2012. 'The Chinese model of a regulatory state'. In D. Levi-Faur (ed.), Handbook on the Politics of Regulation. Cheltenham: Edward Elgar 2012: 142-55.

Gourevitch, Peter 1978. '2nd Image Reversed: International Sources of Domestic Politics'. International Organization 32(4): 881-911.

Green, Stephen 2013. 'China - Masterclass: What Makes 40 Million Local Government Officials Tick?' Hong Kong: Standard Chartered On the Ground. April 2013.

Hale, Galina and Cheryl Long 2010. What Are the Sources of Financing of the Chinese Firms? Hong Kong: HKIMR Working Paper No. 19/2010.

Heep, Sandra 2014. China in Global Finance. Domestic Financial Repression and International Financial Power. New York: Springer International Publishing.

Heep, Sandra 2017. 'The role of government in the banking and financial systems'. In S. Heilmann (ed.), China's Political System. Lanham: Rowan and Littlefield 2017: 212-217.

Heilmann, Sebastian 2005. 'Regulatory Innovation by Leninist Means: Communist Party Supervision in China's Financial Industry'. The China Quarterly 181 (March 2005): 1-21.

Heilmann, Sebastian 2008. 'From local experiments to national policy: The origins of China's distinctive policy process'. The China Journal 59 (2008): 1-30. 
Heilmann, Sebastian 2011. 'Making Plans for Markets: Policies for the Long Term in China'. Harvard Asia Quarterly 13 (2): 33-40.

Heilmann, Sebastian, and Elizabeth Perry (eds.) 2011. Mao's Invisible Hand: The Political Foundations of Adaptive Governance in China. Cambridge, MA: Harvard University Press.

Herd, Richard, Samuel Hill and Charles Pigott 2010. China's Financial Sector Reforms. Working Paper No. 747. OECD Economics Department.

Huang, Hui 2010. 'Institutional Structure of Financial Regulation in China: Lessons from the Global Financial Crisis'. Journal of Corporate Law Studies 10(1): 219-254.

Huang, Yasheng, Saich, Tony and Edward Saul Steinfeld (eds.) 2005. Financial Sector Reform in China. Cambridge, MA: Harvard University Press.

Kroszner, Randall S. and Philip E. Strahan 2000. Obstacles to Optimal Policy: The Interplay of Politics and Economics in Shaping Bank Supervision and Regulation Reforms. Chicago: The Centre for Research in Security Prices Working Paper No. 512. February 2000.

Lardy, Nicholas R. 2014. Markets Over Mao: The Rise of Private Business in China. Washington: Peterson Institute for International Economics.

Levy-Faur, David 2012a. 'Regulation and Regulatory Governance'. In D. Levy-Faur (ed.) Handbook on the Politics of Regulation, Cheltenham: Edward Elgar 2012: 3-23.

Levi-Faur, David 2012b. 'The regulatory state and regulatory capitalism: An institutional perspective'. D. Levi-Faur (ed.) Handbook on the Politics of Regulation, Cheltenham, Edward Elgar Publishing. 2012: 662-71.

Mayntz, Renate 2012 (ed). Crisis and Control. Institutional Change in Financial Market Regulation. Frankfurt am Main: Campus.

Mayntz, Renate, and Fritz W. Scharpf (eds.) 1996. Gesellschaftliche Selbstregelung und Politische Steuerung. Frankfurt/New York: Campus.

Moody's Investor Service 2013. China: Liquidity Crunch, 24 June 2013.

Nee, Victor, and Sonja Opper 2012. Capitalism from Below: Markets and Institutional Change in China. Cambridge, MA: Harvard University Press.

North, Douglas C. 1991. Institutions, Institutional Change and Economic Performance. Cambridge / New York: Cambridge University Press.

Pearson. Margaret M. 2007. 'Governing the Chinese Economy: Regulatory Reform in the Service of the State'. Public Administration Review, July/August (2007): 718-730.

Pearson, Margaret M. 2011. 'Variety Within and Without: The Political Economy of Chinese Regulation'. In S. Kennedy (ed.) Beyond the Middle Kingdom. Comparative Perspectives on China's Capitalist Transformation. Stanford: Stanford University Press 2011: 15-43.

People's Bank of China (PBOC) 2015a. Financial Stability Report China. Beijing: PBOC.

Ping, Xie, Chuanwei Zou, and Haier Liu 2016. Internet Finance in China: Introduction and Practical Approaches. London \& New York: Routledge.

Prasad, Eswar 2016. Gaining Currency. The Rise of the Renminbi. New York: Oxford University Press.

Standard and Poor's 2013. Why Shadow Banking is yet to Destabilize China's Banking System. March 2013.

Shih, Victor 2007. Factions and Finance in China: Elite Conflict and Inflation. New York: Cambridge University Press.

Subacchi, Paola 2017. The People's Money. How China is Building a Global Currency. New York: Columbia University Press.

Takeshi, Jingu 2014. 'Internet finance growing rapidly in China'. Normura Research, Iakyara 189 (2014), 10 March 2014.

Tsai, Kellee 2015. 'The Political Economy of State Capitalism and Shadow Banking in China'. Issues \& Studies 51(1): 55-97. 
Michiel Haasbroek and Jörn-Carsten Gottwald

Vogel, Steven K. 1998. Freer Markets, More Rules. Ithaca: Cornell University Press.

Walter, Andrew 2010. 'Chinese Attitudes towards Global Financial Regulatory Cooperation: Revisionist or Status Quo?' In E. Helleiner, S. Pagliari and H. Zimmermann (eds.) Global Finance in Crisis: The Politics of International Regulatory Change. London/New York: Routledge: 153-169.

Walter, Carl E. and Fraser J.T Howie 2011. Red Capitalism, The Fragile Financial Foundation of China's Extraordinary Rise. Singapore: John Wiley and Sons.

Williamson, Oliver E. 1998. The Economic Institutions of Capitalism. New York, NY: Free Press.

Wong, Christine 2011. 'The Fiscal Stimulus Programme and Public Governance Issues in China'. OECD Journal on Budgeting 3: 1-20.

Yu Yongding 2010. The Impact of the Global Financial Crisis on the Chinese Economy and China's Policy Respons. Third World Network. Penang: MacAlister 